\title{
IMPLEMENTASI PENDIDIKAN AGAMA DAN KE AGAMAAN PASCA KONFLIK DI MAN ADO
}

\author{
Oleh: Sirajuddin Ismail
}

Abstract
This research aims to describe implementation of religion education.
This was conducted at Manado, North Sulawesi. Data was collected by
depth interview and observation.
This research indicates that implementation of religion education is
running normally. Education problem in Manado is decreasing number
of teacher.

Keyword: implementation, education, religion.

\section{PENDAHULUAN}

$\mathrm{B}$ angsa Indonesia, adalah bangsa yang hetrogen dan kemajemukan itu telah melahirkan perpaduan yang sangat indah, yaitu masyarakat dapat hidup berdampingan secara damai dalam berbgai bentuk kultur, berbagai suku dan agama. Namun keragaman yang terajut indah itu terkadang dikoyak oleh promodialisme sempit kcsukuan, agama dan golongan yang banyak mendatangkan dampak negatif dari pada positifnya.

Di samping itu era globalisasi juga menghadapkan masyarakat kepada serangkaian tantangan baru bcrupa pemikiran/faham yang berdampak luas terhadap hidup dan kehidupan umat manusia tidak terkecuali pendidikan agama dan keagamaan. Oleh sebab itu tampaknya pendidikan agama dan keagamaan melalui institusi dan media tentang keberhasilannya masih dipertanyakan akibat dari berbagai ketegangan yang terjadi dalam kehidupan masyarakat. Sejak tahun 
Sirajuddin Ismail

1996 peristiwa ketegangan berupa prasangka, sterotif, bahkan sampai pada tingkat konflik, sedangkan unsur utama dan dasar dari pada prasangka stereotif dan konflik, adalah berupa kepercayaan dan sikap. Namun demikian akibat perebutan sumber daya manusia itu terjadi ketegangan dan kesenjangan social berupa prasangka, stereotif bahkan konflik. Kesenjangan social terjadi dibeberapa daerah, antara lain seperti Lampung, Ambon, Ternate, Poso, Mataram bahkan jauh sebelumnya terjadi pula di Aceh. Ketegangan tersebut baik dalam segala kecil, besar, bernuansa sara', politik, ekonomi dan berdampak pada korban harta, kehormatan bahkan jiwa, dan berpengaruh pula pada berbagai tatanan hidup masyarakat dan institusi sosial, antara lain institusi pendidikan.

Pada saat ini terjadi ketimpangan proses sosialisasi tidak terhindarkan dampak ketegangan sosial tersebut juga nampak pada pendidikan agama dan keagamaan. Pendidikan agama dan keagamaan terkadang tidak menghidupkan pendidikan multicultural yang baik, bahkan cenderung berlawanan. Pendidikan agama dan keagamaan disuatu lembaga pendidikan terkadang masih menafikan pendidikan dan hak hidup agama lain, hal ini terjadi dikalangan mayoritas maupun minoritas. Semangat pendidikan agama dan keagamaan seperti ini berlawanan secara fundamental dengan semangat pendidikan multicultural dan melemahkan kesatuan dan persatuan bangsa.

Masalah pokok dalam penelitian ini, adalah Implementasi pendidikan agama dan keagamaan pasca konflik di Kota Manado. Dari masalah pokok tersebut secara rinci dirumuskan, apa dan bagaimana konflik yang terjadi, bagaimana dampak konflik terhadap implementasi pendidikan agama dan keagamaan, dan bagaimana kebijakan pemerintah terhadap pendidikan agama dan keagamaan pasca konflik di Kota Manado. Penelitian ini dilakukan di Provinsi Manado. Penelitian ini bersifatkualitatif, teknik pengumpulan menggunakan data sekunder dan data data primer melalui wawancara mendalam dan obesrvasi dengan informan terkait.

\section{HASIL PENELITIAN}

\section{a. Setting lokasi}

Sejarah kota Manado, sangat sedikit sumber tertulis yang otentik yang bisa dijadikan rujukan. Sebagaimana halnya asal usul suku dan etnis di Sulawesi Utara, data tentang asal usul Kota Manado hanya diperoleh melalui catatan para Penginjil dan catatan orang Barat. Salah satu diantaranya catatanpendeta Montanus yang pernah menetap di Manado pada tahun 1674, dan berhasil mengumpulkan cerita rakyat tentang kerajaan tua di Sulawesi Utara, salah satu diantaranya, adalah tentang Kerajaan Manado. 
Kerajaan Manado membentang sampai ke dan meluas terus ke Barat sampai di Koeranga, yang terletak diperbatasan dengan Gorontalo. Ke Utara terbentang hingga ke ujung Utara Poelisan (Tanjung Pulisan yang masyarakatnya masih menganut kepercayaan animisme dan dinamisme), tanjung ini terdiri atas pulaupulau di sekitar selat Bangka (Lembe) di Timur Laut dan pantai Barat dan kepulauan ini merupakan salah satu kerajaan. Leluhur Raja Manado (raja Bolaang Mongondow yang bernama Loloda Mokoagow) yang memerintah di kawasan itu ketika pendeta Montanus berada di Manado dan menguasai negeri Bonton (Mouton) dengan bantuan raja Siauw, raja Loloda menaklukan kerajaan Kaudipan. Kerajaan ini terdiri dari dua wialayah yaitu Dauw dan Bolaang Itang dan pada suatu perjanjian Dauw masuk dalam kekuasaan kerajaan Manado, sedangkan Bolaang Itang menjadi wilayah kekuasaan kerajan Siauw. Ada suatu pendapat yang menungkapkan, bahwa raja Manado tidak pernah mempunyai hak di pedalaman Sulawesi (Minahasa).

Penamaan Manado itu sendiri terdapat berbagai versi, Pertama, menurut Dr. Sam Ratulangi dan Dr. Adriani nama Manado berasal dari kata Manarow (bahasa Tontemboan, salah satu sub bahasa di daerah Minahasa) yang berarti sesuatu yang terletak di depan". Kedna, menurut J.GF. Riedel, di dalam bukunya Het oppergezag der vorsten van Bolaang over de Minahasa, bahwa nama Manado berasal dari kata Manaror ( $\mathrm{j}^{\mathrm{g}} \mathrm{g}$ dalam bahasa Tontemboan) yang berarti tempat orang berkumpul. Ketiga, menurut Bert Supit kata Manado sebenamya berasal dari kata Maadon, yaitu nama sebuah sub etnis di Sulawesi Utara yang dahulu kala mendiami pulau Manado Tua. Mereka kemudian pindah ke daerah Manado (yaitu Kota Manado sekarang), dan merupakan cikal-bakal penduduk asli Manado.

Secara gegrafis Kota Manado berbatasan dengan tiga buah kecamatan di Kabupaten Minahasa. Di sebelah Utara ia bebatasan dengan Kecamatan Wori dan Teluk Manado, di sebelah Timur berbatasan dengan Kecamatan Dimembe, di Selatan Kecamatan Pineleng, sedangkan di sebelah Barat Teluk Manado/ Laut Sulawesi. Secara administratif, Kota Manado memiliki luas wilayah sebesar $157.26 \mathrm{Km}^{2}$ dan terbagi ke dalam sembilan wilayah kecamatan dan 87 kelurahan dan desa. Kecamatan yang memiliki jumlah kelurahan/desa yang terbanyak adalah Kecamatan Wenang dan Tikala, yaitu masing-masing 12 buah desa/ kelurahan. Namun, Kecamatan Sario yang saat ini memiliki jumlah desa/ kelurahan yang tersedikit (7) kelurahan dan/desa. Kecamatan yang terluas wilayahnya adalah Kecamatan Mapanget, 37,01\% dari seluruh kecamtan dalam wilayah Kota Manado kemudian menyusul Kecamatan Bunaken, 28,35\%, lalu Kecamatan Malalayang $10,88 \%$. Sedangkan kecamatan yang memiliki wilayah 
terkecil adalali Kecamatan Wenang, 2,31 \% dan Kota Manado memiliki topografi tanah yang bervariasi, berbukit dan dataran yang landai.

Kehidupan beragama Kota Manado, sebagaimana kota lainnya di Indonesia, masyarakatnya menganut agama yang secara resmi diakui oleh negara, yaitu agama Islam, Kristen, Katolik, Hindu dan Budha, sedangkan Kon Futsu belum datanya karena mereka masih tergabung dalam agama Budha (dahulu mereka satu Bimas). Keadaan penduduk kota Manado berdasarkan agama, terkadang berbeda data dari BPS dan data dari Departemen Agama. Data BPS 251.974 Kristen, 136.694 Islam, 33.170 Katolik, 9.967 Hindu dan 6.658 beragama Budha. Sedangkan data Depertemen Agama, 249670 Kristen, 171.742 Islam, 25.046 Katolik, 4.808 Hindu dan 8.290 Budha. Perbedaan data ini karena perbedaan melihat acuannya, yaitu BPS melihat mulai mereka dianggap beragama yang sudah dewasa dalam Kristen setelah"sidi, sedangkan Depertemen Agama melihat mereka sejak remaja.

\section{b. Profil konflik, Pendidikan agama dan Keagamaan.}

\section{Konflik}

Seperti telah dikemukakan bahwa konflik tidak terjadi di Kota Manado hanya konflik yang berupa stereotif yang menjadi salah satu sumber konflik itu sendiri, di samping itu Kota Manado menjadi tempat menggungsi para eksudus dari daerah konflik. Konflik sangat terkait dengan manusia dan kemanusiaan, masalah yang dihadapi oleh manusia adalah memenuhi dorongan kebutuhan yang bersumberpadajasmaniah, kehidupan sosial dan kejiwaannya.

Sering kali keinginan yang akan dipenuhi tersebut bukan sesuatu yang mendasar hanya untuk dapat melangsungkan kehidupannya dilihat dari adaptasi sosiologis terhadap lingkungannya tetapi keinginan yang terkait dengan usaha untuk dapat hidup lebih baik dari hari kemarin atau dari orang lain. Sumber konflik, adalah 1) kepentingan, adalah obyek kebutuhan atau keinginan yang menjadi sumber konflik, yaitu dua pihak mempunyai kebutuhan dan keinginan yang sama terhadap obyek yang disengketakan, antara lain misalnya barang dan jasa layanan, 2) kekuasaan, adalah kebutuhan atau keinginan yang menjadi sumber konflik, yaitu kedua pihak mempunyai kebutuhan dan keinginan yang sama untuk memperoleh status dan peran sehingga memiliki hak dan kewenangan tertentu yang dominan, 3) hak, adalah obyek kebutuhan atau keinginan yang menjadi sumber konflik, yaitu dua pihak mempunyai kebutuhan dan keinginan yang sama untuk memperoleh tuntutannya karena masing-masing merasa bahwa tuntutan itu berkaitan dengan kekuasaan, kewenangan dan tanggung jawab. 
Bertolak dari kenyataan tersebut maka semakin dirasakan perlunya kebijakan multikutural yang memihak keragaman, diharapkan masyarakat dapat mengelola perbedaan yang ada secara positif, sehingga perbedaan dalam keragaman area hidup dan kehidupan tidak memicu prasangka, steriotif dan konflik, persaingan dan diskriminatif dalam masyarakat Indonesia termasuk dalam masalah pendidikan agama dan keagamaan.

Konsep tersebut menunjukan, bahwa timbulnya konflik berasal dari stereotifdan prasangka yang terjadi dalam hidup dan kehidupan manusia, hal ini bisa terjadi akibat dari ulah manusia di dalam memperebutkan sumberdaya di dalam memenuhi kebutuhan hidup sebagai manusia. Namun demikian akibat dalam perebutan sumber daya manusia itu terjadi ketegangan berupa prasangka, stereotif bahkan konflik. Di Kota Manado tidak terjadi konflik terbuka hanya berupa stereotif yang terjadi antara Muslim dengan non Muslim, antara mayoritas Nasrani dengan minoritas agama lain terutama Muslim dalam masalah agama.

Konflik (stereotif) dalam masalah pendidikan agama tidak berhenti sampai pada tahun 1989, tetapi berlanjut pada masalah Rancangan Undang-Undang (RUU) Sistem pendidikan nasional pada tahun 2003, masih dengan lagu lama malah lebih ideal, sehingga mereka mempersoalkan piagam Jakarta dan ingin menjadikan Manado sebagai serambi Betlehem dan membsntuk pejuangyang dikenal dengan Brigade Manguni (Kristen) dan Ligium Kristiani (Katolik).

\section{b. Pendidikan keagamaan.}

Sejarah pendidikan keagamaan (pendidikan Islam) secara tertulis tidak diperoleh, hanya berupa foklor yang dituturkan oleh informan sesuai dengan pengetahuan dan pengalaman atau sebagai pelaku sejarah dalam hubungan dengan pendidikan agama dan keagamaan di Kota Manado.

Sebenamya pendidikan keagamaan sudah ada sebelum zaman Belanda (VOC) tahun 1602 M.Ada yang berpendapat masuknya Islam di Kota Manado sebagai akibat dari peperangan yang terjadi dan dipimpin oleh para pejuang dan syuhadah, yaitu 1) perang Palembang yang berakibat dibuangnya Sultan Badaruddin II ke Manado sebagai akibat kalah perang pada tahun $1821 \mathrm{M}$, pembuangan Baginda Sultan dipindahkan di Temate dan meninggal pada tahun 1825 M, 2) perang Diponegoro yang menyebabkan Pangeran Diponegoro di buang di Kota Manado tahun 1825 M, 3) perang Paderi yang dipimpin oleh Imam Bonjol yang menyebabkan Imam Bonjol di buang di Pinele Minahasa. 
Hasan Yan (Prof). Tahun 1930, madarsah Sullamul Falah dan didirikan PGA dan dipimpin (kepala sekolah) Zainuddin (mantan Kepala Kantor Departemen Agama) Sulawesi Utara.

Dalam dinamikanya pendidikan keagamaan Islam di Manado beradasarkan data dari Departemen Agama Kota Manado (seksi Pekapontren), hanya memiliki 17 diniyah, 4 (empat) Pondok Pesantren, 24 buah RA (Raodatul Atfal).

\section{c. Pendidikan agama.}

Keputusan Menteri Agama Republik IndonesiaNomor. 6 tahun 1979 sebagai penjabaran Keputusan Presiden No.30 tahun 1978, ditetapkan tugas pokok direktorat pembinaan pendidikan agama Islam pada sekolah umum Negeri yaitu melaksanakan sebagian dari tugas pokok Direktorat Jenderal Pembinaan kelembagaan agama Islam di bidang pembinaan pendidikan agama Islam pada sekolah umum dan bertugas sebagai, 1) mempersiapkan kebijaksanaan teknik di bidang pembinaan pendidikan agama Islam pada sekolah umum, 2) melaksanakan pembinaan pendidikan agama Islam pada sekolah umum dan kejuruan yang meliputi kurikulum, pendidik dan sarana pendidikan agama Islam, 3) melakukan pengawasan dan evaluasi atas pelaksanaan pendidikan agama Islam pada sekolah umum dan kejuruan, 4) melakukan pengendalian pelaksanaan pendidikan agama Islam pada sekolah umum dan kejuruan, 5) mengumpulkan dan mengelola data yang diperlukan bagi penyusunan rencana peningkatan dan penyempurnaan pembinaan pendidikan agama Islam pada sekolah umum dan kejuruan serta pembinaan pengawasan pendidikan agama Islam, 6) melaksanakan bimbingan dan pembinaan terhadap pengwas pendidikan agama Islam.

Undang-undang No 2 tahun 1989 tentang Sistem pendidikan nasional disingkat UUSPN. Pendidikan nasional bertujuan mencerdaskan kehidupan bangsa dan mengembangkan manusia Indonesia seutuhnya, yaitu manusia yang beriman dan bertakwa kepada Tuhan Yang Maha Esa dan berbudi pekerti luhur, memiliki pengetahuan dan keterampilan kesehatan jasmani dan rohani, berkepribadian yang mantap dan mandiri serta tanggung jawab kemasyarakatan dan kebangsaan.

Dalam dinamikanya pendidikan agama berkembang sesuai dengan kondisi masyarakat dan perkembangan pembangunan bangsa Indonesia disegala bidang. Pengembangan pembangunan di bidang pendidikan bukan hanya pada pendidikan keagamaan tetapi berkembang hingga pendidikan agama, walaupun masyarakat hanya mengenal segala aspek pendidikan yang berhubungan dengan agama dikenal dengan pendidikan agama. 


\section{d. Implementasi Pendidikan agama.}

Implementasi pendidikan agama, mengacu pada Undang-Undang Republik Indonesia, Undang-Undang Nomor 20 tahun 2003 tentang Sisdiknas dan Peraturan Pemerintah Republik Indonesia (PP) Nomor 55 tahun 2007 tentang Pendidikan agama diatur pada fasal 3 ayat (1), bahwa setiap satuan pendidikan pada semua jalur, jenjang dan jenis pendidikan wajib menyelenggarakan pendidikan agama. Fasal 4 ayat (2) setiap peserta didik pada satuan pendidikan disemua jalur, jenjang dan jenis pendidikan berhak mendapat pendidikan agama sesuai dengan agama yang dianut dan diajar oleh pendidik yang seagama. Fasal 5 ayat (3) Pendidikan agama mendorong peserta didik untuk taat menjalankan ajaran agamanya dalam kehidupan sehari-hari dan menjadikan agama sebagai landasan etika dan moral dalam kehidupan pribadi, keluarga, masyarakat, bangsa dan bernegara. Fasal 7 ayat (1) satuan pendidikan yang menyelenggarakan pendidikan agama tidak sesuai dengan ketentuan sebagaimana dimaksud dalam fasal 3 ayat (1), fasal 4 ayat (2) dan fasal 5 ayat (1) dikenakan sanksi administratif berupa peringatan sampai dengan penutupan setelah diadakan pembinaan/ pembimbingan oleh pemerintah dan/atau pemerintah daerah.

Pendidikan keagamaan diatur pada fasal 8 ayat (1) pendidikan keagamaan berfungsi mempersiapkan peserta didik menjadi anggota masyarkat yang memahami dan mengamalkan nilai-nilai ajaran agamanya dan/atau menjadi ahli ilmu agama, ayat'(2) pendidikan keagamaan bertujuan untuk terbentuknya peserta didik yang memahami dan mengamalkan nilainilai ajaran agamanya dan/atau menjadi ahli ilmu agama yang berwawasan luas, kritis, kreatif, inovatif, dan dinamis dalam rangka mencerdaskan kehidupan bangsa yang beriman, bertakwa dan berakhlak mulia. Fasal 9 ayat (2) pendidikan keagamaan diselenggarakan padajalur pendidikan formal, nonformal dan informal. Fasal 10 ayat (1) Pendidikan keagamaan menyelenggarakan pendidikan ilmu-ilmu yang bersumber dari ajaran agama, ayat (2) yang memadukan ilmu agama dan ilmu umum/keterampilan terutama bertujuan untuk mempersiapkan peserta didik pindah padajenjang yang sama atau melanjutkan kependidikan umum atau yang lainnya pada jenlembaga pendidikan agamajang berikutnya.

Oleh sebab itu pendidikan agama, adalah pendidikan agama yang dilaksanakan pada sekolah umum dan madrasah yang bertujuan memenuhi fasal 37 ayat (1) dan dibina oleh Seksi Mapendais Kantor Departemen Agama, sedangkan pendidikan keagamaan, adalah pendidikan agama yang dilaksanakan 
pada lembaga pendidikan agama dan bertujuan memenuhi fasal 15 tentang pendidikan keagamaan dan dibina oleh seksi Pekapontren Kantor Departemen Agama.

Peraturan Pemerintah tentang pendidikan agama tersebut seirama dengan pendapat A.Azizy, bahwa pendidikan agama mencakup dua hal a) mendidik siterdidik untuk berprilaku sesuai dengan nilai atau akhlak Islam, b) mendidik siterdidik untuk mempelajari materi ajaran Islam, yaitu subyek berupa ilmu pengetauan tentang ajaran Islam. Pendidikan keagamaan (disekolah) dominan pendidikan agama (a), yaitu pendidikan tersebut untuk berprilaku sesuai dengan nilai atau akhlak. Sedangkan pada pendidikan di madrasah dominan yang kedua (b), tetapi keduanya (a) dan (b) harus diterapkan dan diusahakan untuk diwujudkan baik disekolah (umum) maupun di Madrasah. Kegagalan pembentukan individu, nilai yangberimplikasi sosial (moralitas social atau etika social) hampirtidak mendapat perhatian serius. (2003:22)

Oleh sebab itu penekanan terpenting dari pendidikan agama (Islam), adalah hubungan terutama hubungan dengan sesama manusia (тиа'amalah bayna al-nas) dan terkait dengan pengertian agama yang dikemukan oleh Parsudi Suparlan, adalah seperangkat aturan dan peraturan yang mengatur hubungan manusia dengan Tuhan, mengatur hubungan manusia dengan manusia lainnya dan mengatur hubungan manusia dengan lingkungannya. $(1982,86)$

Pembaharuan sistem pendidikan memerlukan strategi tertentu, strategi Pembangunan pendidikan nasional, meliputi a) pelaksanan pendidikan agama serta akhlak mulia, b) pengembangan dan pelaksanaan kurikulum berbasis kompetensi, c) proses pembelajaran yang mendidik dan dialogis, d) evaluasi, akreditasi, dan sertifikasi pendidikan yang memberdayakan, e) meningkatkan keprofesionalan pendidik dar. icnaga kependidikan, f) penyediaan sarana belajar yang mendidik, g) pembiayaan pendidikan yang sesuai dengan prinsip pemerataan dan berkeadilan, h) penyelenggaraan pendidikan yang terbuka dan merata, i) peleksanaan wajib belajar, y) pelaksanaan otonomi manajemen pendidikan, k) pemberdayaan peran masyarakat, 1) pusat pembudayaan dan pembangunan masyarakat, m) Pelaksanaan pengavvasan dalam sistem pendidikan nasional.

Kerangka tersebut menunjukan, bahwa pembangunan pendidikan nasional meliputi berbagai struktur pendidikan baik pendidikan agama dan keagamaan, pengembangan, pelaksanan kurikulum dengan melibatkan berbagai unsuryang mendukung keoerhasilan suatu proses pembelajaran dan pencapaian tujuan pendidikan nasional. Artinya strategi tersebut diharapkan visi, misi dan tujuan 


\section{Sirajuddin Ismail}

pendidikan nasional dapatterwujud secara efektif dengan melibatkan berbagai pihak secara aktif dalam penyelenggaran pendidikan. Pembaharuan sistem pendidikan nasional perlu disesuaikan dengan pelaksanan otonomi daerah sebagaimana diatur dalam undang-undang Republik Indonesia Nomor 22 tahun 1999 tentang Pemerintahan Daerah dan Undang-Undang Republik Indonesia nomor 25 Tahun 1999 tentang Perimbangan keuangan antara pemerintah Pusat dan Daerah.

Telah dikemukakan, bahwa pendidikan agama adalah pendidikan agama di sekolah umum (Diknas) dan pendidikan agama di madrasah (binaan Mapendais), berdasarkan konsep itu maka madrasah yang termasuk pendidikan agama di Kota Manado, adalah 20 Radatul Atfal (RA), 7 (tujuh) Madrasah Ibtidaiyah (MI), terdiri atas 2 madrasah ibtidaiyah negeri (MIN) dan 5 MIS (madrasah ibtidaiyah swasta). 9 (sembilan) buah Madrasah Tsanawiyah (hanya satu) yang status negeri. 5 (lima) Madrasah Aliyah (MA) dan hanya satu yang status negeri.

Guru Pendidikan Agama Islam (PAI) pada berbagai jenjang pendidikan baik lembaga pendidikan negeri maupun swasta mulai dari tingkat TK (Taman Kanak-Kanak), hingga pada tingkat SMA/SMK di Kota Manado, yaitu:

a) Raodatul Atfal (RA): terdapat 20 RA dengan jumlah murid 417 dengan dibina oleh 7 orang tenaga pendidik (semuanya NIP 13) dan berdasarkan analisis Kantor Departemen Agama Kota Manado kekurangan 16 orang pendidik.

b) Sekolah dasar (SD) perkecamatan yaitu (1). Sario: 5 SD, 646 murid Muslim, 1 guru PAI dan kurang 2 orang guru PAI. (2). Wanea: 20 SD, 3003 murid Muslim, 8 guru PAI NIP. 15, dan 2 guru NIP. 13, dan kurang 4 guru PAI. (3). Wenang: 24 SD, 4411 murid Muslim, 16 Guru PAI NIP. 15 $=8$ orang, NIP. $13=8$ orang dan kurang 8 orang guru PAI. (4). Tikala: 30 SD, 4327 murid Muslim, 18 guru PAI. NIP. $15=4$ orang, NIP. $13=14$ Orang dan kurang 6 guru PAI. (5). Malalayang: 12 buah SD, 9980 murid Muslim, 3 guru PAI. NIP. $15=2$ orang. NIP. $13=1$ orang dan kurang 6 guru PAI. (6). Singkil: 15 SD,3341 murid Muslim, 11 guru PAI. NIP. 15 $=2$ guru, NIP. $13=9$ guru dan kurang 2 guru PAI. (7). Tuminting: 24 SD, 3746 murid Muslim, 21 guru PAI. NIP. $15=1$ guru, NIP. $13=20$ guru dan kurang 1 guru PAI. (8). Mapanget: 9 SD, 3285 murid Muslim, 5 guru PAI. NIP. $15=1$ guru, NIP. $13=4$ guru dan kurang 2 guru PAI. (9). Kecarnatan Bunaken: 7 SD, 815 murid Muslim, 1 guru PAI. NIP. 13 dan kurang 3 guru PAI. 
Hasil rekapitulasi Guru PAI pada Kantor Departemen Agama Kota manado tersebut menunjukan, bahvva pada 145 SD dengan 32.655 murid Muslim hanya dibina oleh 84 guru yang seharusnya harus dibina oleh 109 guru PAI.

Kerangkatersebut menunjukan, bahvvajumlah SD dan jumlah murid Muslim pada Sekolah Dasar seluruh Kota Manado padajenjang pendidikan SD membutuhkan 25 pendidik (guru PAI), artinya di Kota Manado kekurangan $22.93 \%$ guru PAI. Di samping itu, bahwa pada 84 guru PAI, yang NIP. 15 hanya $21(25 \%)$, sedangkan selebihnya ber NIP. 13 terdiri atas 64 orang.

c) Jenjang Sekolah Menengah Pertama(SMP) perkecamatan yaitu (1). Sario: 1 SMP, 106 murid Muslim tidak memiliki guru Pendidikan agama Islam (PAI). (2). Wanea: 3 SMP, 690 murid Muslim, 2 guru PAI. (3). Wenang: 5 SMP, 2094 murid Muslim, 3 guru PAI dan kurang 3 guru PAI. (4). Tikala: 4 SMP, 1815 murid Muslim, 3 guru PAI dan kurang 1 guru PAI. (5). Malalayang: 1 SMP, 1012 murid Muslim, 1 guru PAI. (6). Mapanget: 3 SMP, 1001 murid Muslim, 3 guru PAI. (7). Tuminting: 3 SMP, 1589 murid Muslim, 3 guru PAI dan kurang 1 guru PAI. (8). Singkil: 3 SMP, 279 murid Muslim, 1 guru PAI dan kurang 1 guru PAI. (9). Bunaken: 1 SMP, 151 murid, dan tidak memiliki guru PAI.

Kerangka tersebut menunjukan, bahwa berdasarkan analisis kebutuhan guru dan rekapitulasi SMP dan guru PAl Kantor Departemen Agama Kota Manado dan sesuai dengan kuantitas SMP dan murid Muslim, maka pada jenjang Sekolah Menengah Pertama (SMP) sebenarnya harus dibina oleh 23 guru PAI, tetapi yang terpenuhi hanya 16 guru PAI, NIP. $15=13$ orang $(81.25 \%)$, sedangkan NIP. $13=3$ orang $(18.75 \%)$. Pada jenjang pendidikan sekolah menengah pertama kebanyakan $(81.25 \%)$ adalah pembina (guru) NIP. 15. Oleh sebab itu Departemen Agama Kota Manado perlu pertimbangkan pemberian tenaga edukasi (guru) PAI pada jenjang pendidikan SMP.

d) Jenjang SMA jumlah sekolah perkecamatan adalah: (1). Sario: 4 SMA, 2385 murid Muslim, 2 guru PAI dan kurang 1 orang guru PAI. (2). Wanea: 2 SMA, 1254 murid Muslim, 2 guru PAI. (3). Wenang: 2 SMA, 705 murid Muslim, tidak seorangpun guru PAI dan seharusnya diperlukan 3 orang guru PAI. (4). Tikala: 6 SMA, 2272 murid Muslim, 3 guru PAI dan kekurangan 2 guru PAI. (5). Malalayang: Salah satu kecamatan yang tidak ada Sekolah Lanjutan Atas (SMA). (6). Mapanget: 3 SMA, 1114 murid 
Sirajuddin Ismail

Muslim, 3 guru PAI. (7). Tuminting: 2 SMA, 933 murid Muslim, 3 guru PAI, kekurangan seorang guru PAI. (8). Singkil: 2 SMA, 176 murid Muslim, tidak seorangpun guru PAI yang sekurang-kurangnya harus ada seorang guru PAI. (9). Kecamatan Bunaken: tidak ada Sekolah Menengah Atas (SMA).

Mengacu pada analisis kebutuhan guru berdasarkan kuantitas sekolah dan murid menunjukan, bahwa terdapat ketidaksesuaian jumlah guru yang ditugaskan di SMA/SMK dengan jumlah sekolah dan jumlah murid Muslim karena di SMA/ SMK hanya dibina oleh 13 guru PAI yang seharusnyadibina oleh 21 guru PAI. Oleh sebab itu padajenjang pendidikan Sekolah Menengah Atas (SMA/SMK) di Kota Manado masih memerlukan penambahan 8 orang guru PAI untuk memenuhi kebutuhan pembelajaran bidang studi agama Islam. Ke-13 guru PAI tersebut terdiri atas guru PAI NIP. $15=7$ guru, NIP. $13=6$ guru.

Data tersebut belum termasuk guru PAI NIP. 56 (Guru yang diangkat oleh Pemerintah daerah). Perbandingan guru agama NIP 15 (guru agama Islam) semakin kurang dan hampir sampai pada titik yang memprihatinkan, karena sejak tahun 2000 kurang pengangkatan guru agama Islam apa lagi sekarang terdapat peraturan baru yang berhak mengangkat guru pendidikan agama adalah wewenang pemerintah daerah dengan menggunakan NIP. 56 (Otoda). Sedangkan tugas Depertemen Agama hanya berwewenang mengangkat guru pendidikan agama dan pendidikan keagamaan NIP. 15 sesuai dengan kebutuhan. Tetapi yangterjadi dilapangan guru agama didominasi oleh NIP. 13, guru yang diangkat oleh Diknas yang sebenarnya SK mereka bukan SK guru agama, tetapi guru diknas yang diberi tugas mengajar bidang studi pendidikan agama (SK pengangkatannya). Tetapi anehnya Departemen Agama menganggap mereka adalah guru agama, yang sebenarnya mereka tidak lebih dari guru Diknas (guru umum) yang diberi tugas mengajar pendidikan agama karena mereka berlatar belakang pendidikan agama dari segi ijazah.

\section{e. Pendidikan agama pada sekolah Katolik}

Kondisi pendidikan agama pada lembaga pendidikan yang dikelola oleh agama Katolik berdasarkan rekapitulasi sekolah Katolik di Kota Manado tahun 2007 menunjukan, bahwa hampir seluruh kecamatan yang terdapat di Kota Manado terdapat lembaga pendidikan yang dikelola oleh agama Katolik mulai dari jenjang pendidikan Taman kanak-kanak hingga SMA dan semuanya dikelolah oleh 3 yayasan, yaitu Yayasan Pendidikan Katolik (YPK), Yayasan Suster, dan yayasan Frater. Lembaga pendidikan tersebut, adalah 16 TK dengan 783 siswa 
dan 57 guru. 23 SD, 5649 siswa dan 288 guru. 14 SMP dengan 3449 siswa dan 226 guru. SMA/K, 3 SMA, 2026 siswa dan 163 guru. SMA Katolik hanya terdapat di kecamatan Wenang (1), Malalayang (1) dan Takala (1). Dua Kecamatan yang hanya memiliki masing-masing satu lembaga pendidikan Katolik, yaitu kecamatan Sario (SD) dan kecamatan Singkil (SMP) Katolik.

\section{f. Pendidikan agama pada sekolah Kristen.}

Kadaan sekolah yang dibina oleh Yayasan Kristen, yaitu 37 SD di kecamatan Wanea, 36diTikala, 19diMapanget, 31 Wenang, 15 di Singkil, 12 di Sario,31 di Tuminting, 16 di Bunaken dan 18 di kecamatan Malalayang. SMP. 5 SMP di Kecamatan Wanea, 7 di Tikala, 8 di Mapanget, 9 di Wenang, 7 di Tuminting, 5 di Malalayang dan 17 SMA (Sekoalah Menengah Atas). Pendidikan agama Kristen, dibina oleh Pembimbing agama Kristen, demikian juga pendidikan agama Katolik dibina oleh pembimbing agama Katolik. Kedua seksi tersebut membina pendidikan agama Kristen dan agama Katolik mulai dari jenjang Taman-Kanak hingga SMA (Sekolah Menengah Atas).

\section{g. Pendidikan keagamaan.}

Implementasi pendidikan agama dan keagamaan yang diberlakukan sesuai dengan norma yang berlaku di Negara Republik Indonesia dan implementasi pendidikan keagamaan maupun pendidikan agama di madrasah berjalan secara normatif dan tidak terpengaruh oleh dampak konflik sara', walaupun konflik berupa stereotif bagi Muslim secara intern tetap ada dalam masalah khilafiah (pemahaman keagamaan), tetapi tidak nampak dipermukaan karena terdapat masalah ekstern yang mereka hadapi bersama dalam hubungan dengan mayoritas minoritas. Sedangkan dampak konflik (stereotif) terlihat pada pendidikan agama di sekolah umum terutama pada lembaga pendidikan yang dikelola oleh yayasan Nasrani.

\section{h. Dampak Konflik terhadap pendidikan agama.}

Seperti telah dikemukakan, bahhwa konflik tidak pernah terjadi di Kota Manado (Sulut) yang pernah terjadi adalah menjadi salah satu daerah sasaran migran eksodus dari daerah konflik, namun eksodus tidak pernah merusak tatanan hidup masyarakat Kota Manado yang selama ini hidup dengan rukun karena diikat suatu ikatan falsafat torang saтиа basudara. Kehadiran mereka malah membawa angin baik bagi eksodus karena pereka diperhatikan oleh pemerintah segala kebutuliannya selama mengungsi termasuk kebutuhan tentang pendidikan sesuai dengan kondisi daerah, mereka memperoleh pendidikan sama dengan 
Sirajuddin Ismail

persta didik lainnya. Bagi pemerintah daerah dan masyarakat lebih waspada di dalam mengantisipasi pengaruh konflik akibat eksodus yang terdapat di Kota Manado. Mereka diperlakukan sama diberbagai tatanan hidup dan kehidupannya sesuai dengan norma yang berlaku dalam masyarakat Kota Manado.

Stereotipe tampak di permukaan di kota Manado antara kaum Nasrani dengan Kaum Muslimin telah berlangsung lama sejak keberadaan kedua agama ini di Manado. Dalam masalah Pendidikan agama nampak dipermukaan sejak disetujuinya Rancangan Undang-Undang (RUU) tentang Sistem Pendidikan Nasional untuk diundangkan menjadi undang-undang dalam siding pleno DPR pada tanggal 6 Maret 1989. Sejak awal pembahasan RUU itu sampai pada saat disepakati, fraksi dY DPR mempersoalkan penjelasan fasal 38 dan di antara materi atau isi (fasal dan ayat) yang banyak mendapat tanggapan adalah pendidikan agama, yaitu tentang tenaga pengajar pendidikan agama harus beragama sesuai dengan agama yang di ajarkan dan agama peserta didik yang bersangkutan.

Kalangan masyarakat dan pengelola pendidikan, penganut agama Kristiani memberikan tanggapan yang kurang setuju dengan penjelasan tersebut karena dianggapnya dapat merusak tatanan dan akan menghilangkan kebiasaan (ketentuan) yang berlaku di sekolah yang dikelola oleh mereka, dimana siterdidik non Kristiani harus mengikuti pendidikan agama yang dianut oleh pengelola yayasan tersebut.

Kalau dilihat pelaksanaan pendidikan agama disekolah umum yang dibina oleh Kaum Kristiani nampak dampak dari stereotif dalam pelaksanan pendidikan, mereka acuh melaksanakan norma yang dimuat dalam undang-undang sisdiknas Nomor 20 tahun 2003 (seperti telah dikemukakan) dan dijelaskan oleh PP nomor 55 tahun 2007 fasal 4 ayat (2) setiap peserta didik pada satuan pendidikan disemuajalur, jenjang, danjenis pendidikan berhak mendapat pendidikan agama sesuai dengan agama yang dianutnya dan diajar oleh pendidik yang seagama.

Aturan ini tidak jalan dan tidak dipatuhi oleh lembaga pendidikan yang dikelola oleh yayasan Kristiani, kenyatan dilapangan menunjukan, bahwa tidak seorangpun guru pendidikan agama Islam atau guru agama lain selain dari guru agama Kristen dan Katolik. Pada lembaga pendidikan yang dibina oleh Yayasan mereka mulai dari tingkat sekolah dasar hingga SMA, memiliki murid non Katolik, antara lain murid Muslim, yaitu (a) Sekolah Dasar: SD 1 St. Theresia Manado (268=2 orang siswa Muslim), SD 10 St. Theresia Manado (274= 3 orang siswa), SD Don Bosco Manado $(760=10$ orang siswa), (b) Sekolah 
Sirajuddin Ismail

persta didik lainnya. Bagi pemerintah daerah dan masyarakat lebih waspada di dalam mengantisipasi pengaruh konflik akibat eksodus yang terdapat di Kota Manado. Mereka diperlakukan sama diberbagai tatanan hidup dan kehidupannya sesuai dengan norma yang berlaku dalam masyarakat Kota Manado.

Stereotipe tampak di permukaan di kota Manado antara kaum Nasrani dengan Kaum Muslimin telah berlangsung lama sejak keberadaan kedua agama ini di Manado. Dalam masalah Pendidikan agama nampak dipermukaan sejak disetujuinya Rancangan Undang-Undang (RUU) tentang Sistem Pendidikan Nasional untuk diundangkan menjadi undang-undang dalam siding pleno DPR pada tanggal 6 Maret 1989. Sejak awal pembahasan RUU itu sampai pada saat disepakati, fraksi dY DPR mempersoalkan penjelasan fasal 38 dan di antara materi atau isi (fasal dan ayat) yang banyak mendapat tanggapan adalah pendidikan agama, yaitu tentang tenaga pengajar pendidikan agama harus beragama sesuai dengan agama yang di ajarkan dan agama peserta didik yang bersangkutan.

Kalangan masyarakat dan pengelola pendidikan, penganut agama Kristiani memberikan tanggapan yang kurang setuju dengan penjelasan tersebut karena dianggapnya dapat merusak tatanan dan akan menghilangkan kebiasaan (ketentuan) yang berlaku di sekolah yang dikelola oleh mereka, dimana siterdidik non Kristiani harus mengikuti pendidikan agama yang dianut oleh pengelola yayasan tersebut.

Kalau dilihat pelaksanaan pendidikan agama disekolah umum yang dibina oleh Kaum Kristiani nampak dampak dari stereotif dalam pelaksanan pendidikan, mereka acuh melaksanakan norma yang dimuat dalam undang-undang sisdiknas Nomor 20 tahun 2003 (seperti telah dikemukakan) dan dijelaskan oleh PP nomor 55 tahun 2007 fasal 4 ayat (2) setiap peserta didik pada satuan pendidikan disemuajalur, jenjang, dan jenis pendidikan berhak mendapat pendidikan agama sesuai dengan agama yang dianutnya dan diajar oleh pendidik yang seagama.

Aturan ini tidak jalan dan tidak dipatuhi oleh lembaga pendidikan yang dikelola oleh yayasan Kristiani, kenyatan dilapangan menunjukan, bahwa tidak seorangpun guru pendidikan agama Islam atau guru agama lain selain dari guru agama Kristen dan Katolik. Pada lembaga pendidikan yang dibina oleh Yayasan mereka mulai dari tingkat sekolah dasar hingga SMA, memiliki murid non Katolik, antara lain murid Muslim, yaitu (a) Sekolah Dasar: SD 1 St. Theresia Manado (268=2 orang siswa Muslim), SD 10 St. Theresia Manado (274= 3 orang siswa), SD Don Bosco Manado ( $760=10$ orang siswa), (b) Sekolah 
Menengah Pertama (SMP): SMP. Pax Chiristi Manado (715= 4 orang siswa), SMP. Don Bosco Manado (477= 5 siswa), (c) Sekolah Menengah Atas (SMA): SMA. Rex Mundi $(719=2$ orang siswa). SMA. Don Basco Manado (468=6 orang siswa).

Kerangka tersebut menunjukan, bahwa tujuh sekolah yang terdapat di kecamatan Wenang mulai dati tingkat Sekolah dasar (SD) hingga Sekolah Menengah Umum (SMA) memiliki 32 orang siswa yang beragama Islam, secara normatif harus memiliki 7 orang guru pendidikan agama Islam.

Dampak stereotif di dunia pendidikan agama di Kota Manado, salah satu contoh kasus ujian agama, salah seorang murid yang beragama Islam diberikan soal agama Islam, anak tersebut tidak mau menerima soal ujian agama Islam malah dia menangis dan berkata dia tidak pernah belajar agama Islam di sekolah tetapi dia belajar agama Katolik dan kasus ini ditemukan oleh Kepala Seksi Bimas Kristen (Pendeta John Toni Tilaar S.Th). Kernyataannya di sekolah dia belajar agama Katolik (bukan agama Islam) dan belajar agama Katolik suatu kewaj iban yang berlaku di sekolah tersebut dan ketika masuk di sekolah Katolik dia dan orang tuanya menandatangani pernyataan bahwa anak harus mengikuti pelajaran agama Katolik walaupun mereka non Katolik.

Pendidikan agama di sekolah umum lain mulai dari tingkat SD hingga Sekolah Menengah Atas tidak terjadi seperti itu (tidak mengalami dampak stereotif), hanya pendidikan agama mengalami kekurangan guru agama, karena sejak tahun 2000 sangat kurang pengangkatan guru agama Islam, terutama guru agama NIP. 15 guru pengangkatan Departemen Agama, walaupun sekarang terdapat pengangkatan guru agama oleh pemerintah daerah dengan menggunakan NIP. 58. Guru Agama NIP. 15 semakin berkurang di samping kurang pengangkatan guru agama NIP. 15 juga karena banyak guru pensiun sedangkan pengangkatan guru masih dipertanyakan.

\section{j. Kebijakan pemerintah terhadap pendidikan agama.}

Kebijakan pemerintah Kota Manado di dalam mensukseskan program pembangunan disegala bidang pada era otoda termasuk pembangunan di bidang pendidikan agama, artinya pemerintah daerah memiliki kewenangan, yaitu kewenangan untuk mengatur rumah tangganya, menetapkan peraturan daerahnya sepanjang tidak bertentangan dengan kepentingan umum dan peraturan perundang-undangan yang berlaku termasuk masalah pendidikan agama. 


\section{Sirajuddin Ismail}

Hal tersebut diatur dalam undang-undang Otonomi nomor 32 tahun 2004 tentang pemerintah daerah BAB 1 , ketentuan umum fasal 1 poin 5 , bahwa hak wewenang dan kewajiban daerah otonom untuk mengatur dan mengurus sendiri urusan pemerintahan dan kepentingan masyarakat setempat sesuai dengan peraturan perundang-undangan.

Konsep tersebut menunjukan, bahwa pemerintah daerah memegang peranan penting dalam menentukan arah kebijakan, baik berbentuk peraturan daerah maupun berbentuk keputusan, sehingga pemerintah daerah dituntut memiliki kemampuan pengetahuan teknis dalam pelaksanaan suatu aturan daerah secara efektif Sesuai dengan pendapat Lopa, "bahwa efektif tidaknya pelaksanaan suatu peraturan daerah sangat dipengaruhi oleh aparat penegak hukum (termasuk pemerintah) yang professional dan memiliki integritas yang tinggi". (2002 : 2) Hukum sebagai unsur normatif dalam menata kehidupan dalam bentuk dan jenis apapun, berkenaan dengan pengaturan dan kekuasaan. Sedangkan kekuasaan dapat diartikan sebagai kemampuan mempengaruhi dan mengarahkan manusia untuk melakukan atau meninggalkan perbuatan sesuai dengan kehendak (perintah/larangan) yang berkuasa. Oleh sebab itu, kekuasaan memiliki daya atur, daya ikat dan daya paksa hukum dalam penataan kehidupan manusia.

Kebijakan pemerintah Daerah Kota Manado terhadap dampak konflik yang terjadi di daerah lain seperti Maluku, Maluku Utara dan Poso, karena terdapat 600 KK migran di Kota Manado mereka sebagai eksodus dari daerah konflik tersebut. Para eksodus ditempatkan di daerah yang dekat dengan lokasi (instansi) TNI agar mereka aman dan mudah dikordinir. Di samping mereka diperlakukan dengan baik untuk mengantisipasi dampak negatif atas keberadaannya, yaitu mereka dijamin baik materi maupun mental siprituilnya. Mereka diberi tempat di daerah pengungsian dan dijamin biaya hidupnya selama dipengungsian atas biaya APBD Sulawesi Utara, Anak usia sekolah mereka mengikuti pendidikan gratis di sekolah terdekat bersama (gabung) dengan anak-anak masyarakat Kota Manado, artinya pada lemabaga pendidikan terdekat dari tempat pengungsiannya yang akhirnya kebanyakan mereka kembali pasca konflik dan ada diantara mereka yang tidak kembali dan memilih menetap di Kota Manado dengan alasan mereka tidak memiliki lagi harta yang tersisa, di samping trauma akan timbul konflik serupa.

Dari segi pembinaan spiritual memerintah daerah melalui para tokoh agama melakukan pembinaan mental kepada mereka dan dilakukan sesuai dengan jadwal yang ditentukan. Di sekolah ditekankan pada para pendidik agar dalam proses 
pembelajaran lebih menitiberatkan pada muatan yang mengarah pada pemulihan kerukunan umat beragama dan Pendidikan moral Pancasila terutama yang berhubungan dengan keamanan dan kesejahteraan masyarakat.

Departemen Agama (Islam menekankan pada masalah kebaikan (islahj, agama rahmatan lil alainin. Sedangkan agama lain secara bergantian (sesuai jadwal) memberikan bimbingan terhadap eksodus sesuai dengan keparcayaan dan keyakinan mereka, artinya semua agama bergantian memberikan bimbingan terhadap mereka, agar terkesan bahwa mereka merasa diperhatikan dan akan melupakan masa lalunya berada di daerah konflik dan tidak akan mudah terprovokasi oleh pihak yang tidak bertanggung jawab yang ingin menggunakan kesempatan mengeruhkan suasana dan merusak tatanan kehidupan masyarakat Kota Manado.

Pendidikan agama disekolah selain pada sekolah yang dikelola oleh yayasan Kristiani mulai dari tingkat SD hingga SMA tidak terkena dampak stereotif hanya mereka mengalami kekurangan guru pendidikan agama Islam, artinya bukan pelanggaran terhadap PP tetapi berjalan secara alami, sebagai akibat banyak guru agama yang pensiun dan kurang pengangkatn guru agama sejak tahun 2000 dan kalau ada pengangkatan sangat terbatas terutama guru agama NIP 15.

\section{PENUTUP}

\section{Kesimpulan}

Tidak pernah terjadi Konflik terbuka di Kota Manado seperti yang terjadi di daerah lain seperti Poso, Ambon dan Ternate hanya menjadi tempat pengungsian para eksodus dari daerah konflik untuk menyelamatkan diri dari konflik dan yang nampak dipermukaan di Kota Manado adalah konflik berupa stereotif di bidang pendidikan agama.

Implementasi pendidikan agama dan keagamaan berjalan secara normatif, hanya yang terpengaruh dampak stereotif, adalah pelaksanaan pendidikan agama pada sekolah yang dikelola oieh yayasan Kristiani, walaupun pada lembaga pendidikan yang mereka kelola terdapat siswa non Kristiani. Mereka tidak melaksanakan Undang nomor 20 tahun 2003 tentang Sisdiknas dan PP. 55 tahun 2007 fasal 4 ayat (2) bahwa setiap peserta didik berhak mendapat pendidikan agama sesuai dengan agama yang dianutnya dan diajar oleh pendidik yang seagama. 
Sirajuddin Ismail

Kebijakan pemerintah tidak menyentuh dampak konflik (stereotif) tersebut sehingga pelanggaran terhadap Undang-undang nomor 20 tahun 2003 dan PP. nomor 55 tahun 2007 tetap berlangsung, artinya tidak seorangpun pendidik yang beragama lain yang mengajar di sana walaupun lembaga pendidikan tersebut memiliki siswa non Kristiani.

Pada Departemen Agama Kota Manado menunjukan adanya kekurangan guru PAI (Pendidikan Agama Islam), karena setiap tahun banyak guru yang purna bakti, Sejak tahun 2000 kurang pengangkatan guru PAI NIP. 15 (Depag), dan masih terjadi dan termasuk juga NIP. 13 (Diknas), di samping dewasa ini wewenang pengangkatan guru PAI juga dilakukan oleh Pemerintah Daerah (Pemda) dengan NIP. 58 (NIP Pemda).

\section{Rekomendasi}

Hendaknya pemerintah daerah Kota Manado mengamankan UndangUndang Nomor 20 tahun 2003 tentang Sisdiknas dan Peraturan Pemerintah (PP) Nomor 5 tahun 2007 fasal 4 ayat (2) karena konflik (stereotif) tersebut berpotensi akan menimbulkan hal-hal negatif kalau dibiarkan berlarut-larut karena hal itu berhubungan dengan masalah kepercayaan (agama) seseorang warga Negara Republik Indonesia.

Untuk menghindari kekurangan guru PAI di Kota Manado, hendaklah pemerintah meninjau kembali dan mempertimbangkan pemberian wewenang pada Depertemen Dalam Negeri tentang pengangkatan guru agama Daerah (NIP. 58) dan mengembalikan wewenang pengangkatan guru agama pada Departemen Agama dan paling tidak pada Diknas untuk mengangkat dan membina guru PAI (NIP. 15 dan NIP. 13) terutama pengangkatan guru PAI NIP. 15 karena pengaturan masalah agama adalah wewenang dan tanggung jawab Departemen Agama. 
Sirajuddin Ismail

\section{DAFTAR PUSTAKA}

A. Azizy, MAdalam Drs. H. Abdul Hamid M.Ed dan Drs. H. A. Kadir Jaelani M.Pd (Ed) fesionalisme Pengawas Pendais, Depertemen Agama RI Direktorat Jenderal Kelembagaan Agama Islam, Jakarta. 2003.

MA dalam Drs.H.Abdul Hamid M.Ed dan Drs.H.A.Qadir Jailani M.Ed (Ed), Profesionalisme Pengawas Pendais, Departemen Agama RI Direktorat Jenderal Kelembagaan Agama Islam, Jakarta. 2003.

Budiman, dalam A.W Widjaja.Drs, Manusia Indonesia, Individu Keluarga Dan Masyarakat, Akademika Pres Sindo, Jakarta. 1986.

Basri, Hasan Cik, Pilar-pilar Penelitian Hukum Islam Dan Pranata Sosial, Cet. Pertama, PT. Raja Grakindo Persada, Jakarta. 2004.

Djumhur dan Danasaputra, Sejarah Pendidikan, Tjet. Ketiga, Tjerdas, Bandung. 1962.

E.Toeke, Idrus Hi.Drs, Menyatukan Pandangan Dalam Semangat Imani Membangun Maluku Bersaudara, Majelis Ulama Indonesia Provinsi Maluku, Ambon. 2006.

Hasan, dalam Marwan Saridjo, Bunga Rampai Pendidikan agama Islam, CV. Amissco Departemen Agama RI, Direktorat Jenderal Pembinaan Kelembagaan Agama Islam, Jakarta. 1998.

Hazarin dalam Muhammad Daud Ali, Hukum Islam,Pengantar Ilmu Hukum Dan Tata Hukum Islam Di Indonesia, Cet. Kesebelas, PT. Raja Grakindo Persada, Jakarta. 2004.

Ismail, Sirajuddin dalam Muhamad As.ad (Ed), Agama Dalam Dimensi Sosial Dan Budaya Lokal, Studi Tentang Upacara Sikhis Hidup Masyarakat Bolaang Mangondovv, Balai Penelitian Lektur Keagamaan Ujung Pandang, Ujung Pandang. 1998.

Liliwari, Alo.Dr.Prof, Prasangka \& Konflik, Komunikasi Lintas Budaya Masyarakat Multikultur, FK1S Yogyakarta, Yogyakarta. 2005.

Lewis Acoser, dalam Irving M.Zeitlin, Memahami Kembali Sosiologi, Gajah Mada University Press, Yohyakarta. 1998.

Legalitas. Org. Free Indonesian Legal Information, Peraturan Pemerintah Republik Indonesia Nomor 55 Tahun 2007, Tentang Pendidikan Agama Dan Pendidikan Keagamaan, Jakarta. 2007.

Mazhari, Husain (Penerjemah), Pintar Mendidik Anak, Pansuan Lengkap bagi Orang Tua, Guru dan Masyarakat berdasarkan Ajaran Agama Islam, Cet. Keenam, PT. Lentera Basritama, Jakarta. 2003. 


\section{Sirajuddin Ismail}

Muryanis.Hj.Dra.M.Ag dan Drs.H.Romli M.Hum, Pendidikan luarsekolah, Departemen Agama RI Direktorat Jenderal Kelembagan Agama Islam, Jakarta. 2003.

Ngadisa, Konflik Pembangunan Dan Gerakan Sosial Politik di Papua, Pustaka Raja, Yogyakarta. 2003

Suparta, Undang-Undang Dan Peraturaan Pemerintah RI, Tentang Pendidikan, Direktorat Jenderal Pendidikan Islam Departemen Agama RI, Jakarta. 2006.

Suparlan, Parsudi, Pengetahan Budaya, Ilmu-Ilmu Sosial Dan Pengkajian MasalahMasalah Agama, Pusat Penelitian Dan Pengembangan Agama Lektur Agama Badan Litbang Agama, Jakarta. 1982.

Soemantri, RHAS. Drs, pedoman Pelaksanaan Pendidikan Agama Islam pada SD, Cet. Empat, CV. Multiyasa \& Co, Departemen Agama RI Direktorat Jenderal Pembinaan Kelembagaan Agama Islam, Proyek Pembinaan Pendidikan Agama Pada Sekolah Umum, Jakarta. 1986.

Saridjo, Marwan, Bunga Rampai Pendidikan agama Islam, CV. Amissco Departemen Agama RI, Direktorat Jenderal Pembinaan Kelembagaan Agama Islam, Jakarta. 1998.

Taufik Kamil H.Drs, Pengamal an Agama Dalam siklus Kehidupan, Depertemen Agama RI Ditjen Bimas Islam Dan Penyelenggaraan Haji, Proyek Peningkatan Kehidupan Keluarga sakinah, Jakarta. 2003. 